\title{
Application of acidic protease in the pickling to simplify the pelt bating process
}

\author{
Xu Zhang ${ }^{1,2}$, Mengchu Gao ${ }^{1,2}$, Sadaqat Ali Chattha ${ }^{1,2}$, Yiwen Zhu ${ }^{1,2}$, Biyu Peng ${ }^{1,2^{*}}$ (1) and Yongbin Ye ${ }^{3}$
}

\begin{abstract}
Traditionally, universally used pelt bating technologies rely on the application of trypsin, neutral and alkaline microbial proteases but suffer from complicated operation, limited bating efficiency and unsatisfactory leather performance. Therefore, devising a new pelt bating approach to achieve high bating efficiency and excellent leather performance has always been wished for by the leather industry. To pursue this goal, years of persistent research work enabled us to develop a novel approach for pelt bating by means of acidic proteases in pickling process. Initially, basic enzymatic characteristics and bating effectiveness of several typical acidic proteases in pelt pickling medium were investigated; then, the bating effectiveness through the quantitative characterization of protease activity of the optimal acidic protease was compared with that of the conventional bating enzyme. The results indicated that all of the selected acidic proteases had good salt-tolerance and exhibited optimum activity at $\mathrm{pH}$ 3.0-4.0. The novel pickling-bating method based on microbial origin acidic protease L80A led to an outstanding performance on pelt bating at the dosage of $150 \mathrm{U} / \mathrm{mL}$ of collagenolytic activity. The bating effectiveness of acidic protease L80A was comparable to and even better than that of trypsin BEM due to its moderate proteolytic ability. Moreover, the deep and even penetration of acidic protease in the pelt permitted it to produce soft, organoleptically stable and overall better quality crust leather than that of the conventional trypsin bating method. Additionally, pelt bating was performed along with the pickling process without extra inactivation and washing operation, making the bating operation more efficient, economical, and environment friendly. Results had made us to conclude that this cutting-edge acidic proteases based pickling-bating method could be the first step/ way forward to replace the decades-old traditional pelt bating technology.
\end{abstract}

Keywords: Bating, Trypsin, Pickling, Acidic protease, Collagenolytic activity

\section{Introduction}

Bating is one of the most important procedures executed on delimed pelts with the help of enzyme preparations for removing unwanted components and ancillary opening up protein structures [1-5]. Enzymatic bating helps to improve the performance of leather, i.e. uniformity, feeling, softness, pliability, elasticity, etc., because it further opens up the fiber structure of the pelt and thus

\footnotetext{
*Correspondence: pengbiyu@scu.edu.cn

${ }^{1}$ National Engineering Research Center of Clean Technology in Leather Industry, Sichuan University, Chengdu 610065, Sichuan, People's Republic of China

Full list of author information is available at the end of the article
}

makes the penetration of tanning materials into the pelt more expedient $[6,7]$. Therefore, enzymatic bating is an important step in the leather manufacturing process and cannot be substituted by any mechanical and chemical procedure.

In the conventional bating process, pelt bating is carried out in a deliming solution with the help of enzyme preparations at $30-37^{\circ} \mathrm{C}$ and $\mathrm{pH} 7.0-8.5[8,9]$. A mixture of protease and ammonium salt is commonly used in pelt bating process to achieve the maximum proteolysis activity of bating enzymes and buffering effect [2]. However, the discharge of ammonia nitrogen in water may results in eutrophication of aquatic ecosystems. After bating, it is necessary to wash the pelts for the removal of unwanted 
components. Afterwards, the pelts are chrome-tanned through a standard pickling-tanning-basification procedure, which is the most widely used tanning method in leather manufacturing. Pickling is a process in which delimed pelt $(\mathrm{pH}$ is in the range of 7.0-8.5) is acidified in a salt solution with the application of formic acid and sulfuric acid to adjust the end $\mathrm{pH}$ of the float at 2.8-3.0 and modify the reactivity of the carboxyl groups in collagen fibers $[2,10]$. Chrome tanning is carried out with an offer of $6-8 \%$ of chrome powder to give the pelt high hydrothermal stability, mechanical properties, bacterial resistance and organoleptic properties $[2,11]$. Therefore, the conventional bating-washing pickling-chrome tanning process is very complicated, ends up with limited production capacity and a lot of pollution.

In addition, trypsin, a serine protease, is taken as the best enzyme for pelt bating. Trypsin is an endo-protease with high hydrolysis specificity. It preferentially hydrolyses peptide bonds adjacent to arginine and lysine residues $[12,13]$ and this makes its proteolytic ability more moderate and safer than that of other proteases. However, commercial production of trypsin mainly depends on its extraction from bovine pancreatic tissue, which has many disadvantages, such as purity, poor batch stability, unpleasant odor, potential cross-infection, availability of raw material, and damage to mammal immunogenicity, etc. $[14,15]$. The aforementioned disadvantages of trypsin in conventional bating technology restrict its widespread application in the leather manufacturing industry. Although some alternative methods have been proposed to resolve the problems, however, to the best of our knowledge, these approaches have failed to provide the solution so far. For example, microbial neutral and alkaline proteases have particularly been reported to constitute an advisable class of enzymes with promising industrial applications in pelt bating process [16-20]. However, the complexity and low hydrolysis specificity of microbial proteases demand extra care in pelt bating operations to avoid excessive damage to the grain layer and the dermal matrix. However, insufficient opening up of fiber structure and hardened fibers will result in poor-quality wet blue leather production [21, 22]. For the rectification of these problems, another enzymatic bating operation is required on the post-tanning stage, namely wet blue bating. However, wet blue bating operation not only takes a longer time but also needs a larger dosage of enzyme to hit the spot of the finished leather, and thus restricts the production efficiency and increases the production cost [23-25]. Therefore, new developments in the pelt bating field must have to be taken into consideration.

As mentioned above, the end $\mathrm{pH}$ of pickle float is maintained in the range of 2.8-3.0. Therefore, pickle float $\mathrm{pH}$ enables acidic proteases to express their best proteolysis rate as their own optimum $\mathrm{pH}$ fall in the range of 3.0-4.0 $[12,26]$. Our previous research proved that the protease activity to chrome-tanned protein fiber has been significantly reduced compared to the untanned substrate, and well-tanned protein fibers exhibited high protease-resistance ability as well [24]. Similarly, the inactivation of the proteolytic activity of acidic proteases has been achieved by chrome powder (tanning agent) indicating its ability to be used as a quenching agent for the pickling-bating process. All of these characteristics indicate that pickling, pelt bating and chrome tanning can be achieved in a one-bath process without extra inactivation and washing operations.

Within the framework of these criteria, the present work aimed to develop an efficient and eco-friendly onebath pickling-bating-chrome tanning leather manufacturing technique by using acidic proteases in the pickling process. Firstly, the characteristics and bating effectiveness of several typical acidic proteases in pelt pickling medium were investigated comprehensively; then, the bating effectiveness of the novel pickling-bating method was compared with that of the conventional trypsin bating method by optimizing the process parameter. We believe that we have developed an innovative pelt bating method for the leather industry by using acidic proteases which will not only reduce the operation cost but also improve the quality of the finished product.

\section{Materials and methods}

\subsection{Materials}

All proteases (Table 1) and wet-salted cattle hides were purchased from the market. Hydroxyproline (Hypro) and Desmosine (Des) standards were obtained from MembraPure $\mathrm{GmbH}$ (Germany). Collagen fiber powder was prepared by our laboratory from the reticular layer of delimed bovine hide according to the conventional leather processing technology [24, 27]. Elastin fiber powder was also prepared by our laboratory through a hot alkaline process extracted from fresh cattle ligamentum nuchae $[28,29]$. The chemicals used for analytical techniques were of analytical grade, and other chemicals used for leather processing were of commercial grade.

\subsection{Assay of proteolytic activity on casein substrate}

Caseinolytic activity was determined according to the modified Folin method at certain conditions [30, 31]. The proteolysis was performed by incubating $1 \mathrm{~mL}$ of properly diluted enzyme solution with $1 \mathrm{~mL}$ of $1 \%$ $(\mathrm{m} / \mathrm{v})$ casein substrate in Britton-Robinson buffer (B-R buffer, $0.1 \mathrm{~mol} / \mathrm{L}$ ) at $25{ }^{\circ} \mathrm{C}$ for $10 \mathrm{~min}$, precisely. Then, the reaction was quenched by adding $2 \mathrm{~mL}$ of trichloroacetic acid $(0.4 \mathrm{~mol} / \mathrm{L})$ and allowed to be centrifuged at 
Table 1 The selected proteases

\begin{tabular}{lll}
\hline Proteases & Characterization & Company \\
\hline 537 & Acidic bacteria protease & Kunming Qactive Bio-Science Co. Ltd., China \\
AKT & Acidic bacteria protease & Kunming Qactive Bio-Science Co. Ltd., China \\
TP & Acidic bacteria protease & Denykem Co. Ltd., UK \\
L80A & Acidic bacteria protease & Longda Bio-Products Co. Ltd., China \\
BEM & Bovine trypsin & Dowell Science and Technology Inc., China \\
\hline
\end{tabular}

$3500 \mathrm{r} / \mathrm{min}$ for $10 \mathrm{~min}$. Finally, $1 \mathrm{~mL}$ of the supernatant was transferred into a $15 \mathrm{~mL}$ test tube and reacted with $5 \mathrm{~mL}$ of $\mathrm{Na}_{2} \mathrm{CO}_{3}$ solution $(0.4 \mathrm{~mol} / \mathrm{L})$ and $1 \mathrm{~mL}$ of FolinPhenol reagent at $40{ }^{\circ} \mathrm{C}$ for $20 \mathrm{~min}$. After the reaction, the absorbance of the reaction mixture was measured at $680 \mathrm{~nm}$ to determine the amount of tyrosine released during the proteolysis. Unless otherwise indicated, all experiments were conducted in triplicate at least, and results were expressed as the average value of the replicate determinations. One unit of caseinolytic activity is defined as the amount of enzyme capable of digesting the casein substrate to produce $1 \mu \mathrm{g}$ of tyrosine in $1 \mathrm{~min}$ at certain conditions.

2.3 Assay of proteolytic activity on collagen fiber substrate Collagenolytic activity was determined according to the established method by our laboratory [27]. Delimed collagen fiber from the reticular layer of delimed cattle hides was prepared according to conventional leather processing technology and chosen to be the substrate. The amount of Hypro in the digested liquor was tested to appraise the performance of proteases hydrolyzing collagen fiber. In detail, $300 \pm 1 \mathrm{mg}$ of collagen fiber was accurately weighed in a $50 \mathrm{~mL}$ test tube, followed by adding $9 \mathrm{~mL}$ of B-R buffer (contain $80 \mathrm{~g} / \mathrm{L}$ of sodium chloride) and stirred in an incubator for $10 \mathrm{~min}$ at $25^{\circ} \mathrm{C}$ with $200 \mathrm{r} /$ min. Then, $1 \mathrm{~mL}$ of enzyme solution (diluted to a certain concentration by the same B-R buffer) was added and stirred for another $30 \mathrm{~min}$ at $25{ }^{\circ} \mathrm{C}$ with $200 \mathrm{r} / \mathrm{min}$, precisely. Finally, the reaction liquor was filtered with a qualitative filter paper, and the concentration of Hypro in the digested liquor was tested according to the modified colorimetric method [32]. One unit of collagenolytic activity is defined as the amount of enzyme capable of digesting the collagen fiber substrate to produce $1 \mu \mathrm{g}$ of Hypro in 1 min at certain conditions.

\subsection{Effect of salt concentration on the collagenolytic activity of acidic proteases}

As mentioned above, pickling is an important step of standard chrome tanning procedure in which the delimed pelt is acidified in a salt solution with a combination of formic and sulfuric acid to satisfy the chrome tanning conditions. In the conventional chrome tanning process, the pickle float must contain at least $60 \mathrm{~g} / \mathrm{L}$ of sodium chloride (approximately $1 \mathrm{~mol} / \mathrm{L}$ of $\mathrm{NaCl}$ ) to protect the collagen fiber from acid swelling, which would have a serious negative influence on the organoleptic and physical properties of the finished leather. Usually, high concentration of salt may have a negative effect on the proteolytic ability of enzymes [33]. Therefore, the influence of salt on the collagenolytic activity of enzymes needs to be addressed critically. Hence, the salt-tolerant of the selected acidic proteases was studied at $\mathrm{pH} 3.5$, $25{ }^{\circ} \mathrm{C}$, and $50 \mathrm{~g} / \mathrm{L}$ to $120 \mathrm{~g} / \mathrm{L}$ of $\mathrm{NaCl}$ concentration. The relative activity was calculated based on the activity at $50 \mathrm{~g} / \mathrm{L}$ of $\mathrm{NaCl}$ concentration.

The collagenolytic activity was determined by the above-mentioned procedure. A certain amount of salt (sodium chloride) was added into the B-R buffer to make sure that the concentration of $\mathrm{NaCl}$ in the proteolytic reaction liquor should be in the range of $50 \mathrm{~g} / \mathrm{L}$ to $120 \mathrm{~g} / \mathrm{L}$.

\subsection{Bating pickling pelt with typical proteases}

Wet-salted cattle hides from Chinese suppliers were chosen as raw material for this study. All samples from soaking until deliming were processed according to the conventional leather manufacturing technology, such as soaking, fleshing, sulfide liming-unhairing, splitting and deliming. A whole grain-layer limed cattle hide with a thickness of $3.0-3.2 \mathrm{~mm}$ after splitting was divided into pieces adjacently and symmetrically, and distributed to different pickling-bating groups for comparison and evaluation of the bating effects. The delimed pelt was pickled, bated, and chrome tanned with the following procedures: $50 \%$ of water (based on the weight of limed hides, the same below) and $8 \%$ of $\mathrm{NaCl}$ running for $10 \mathrm{~min}$ at $25{ }^{\circ} \mathrm{C} ; 0.5 \%$ of formic acid $(\mathrm{HCOOH})$ running for $30 \mathrm{~min}$; $0.5-0.7 \%$ of sulfuric acid $\left(\mathrm{H}_{2} \mathrm{SO}_{4}\right)$ running for $120 \mathrm{~min}(\mathrm{pH}$ was maintained at $3.5 \pm 0.1$ and if required, additional $\mathrm{H}_{2} \mathrm{SO}_{4}$ was also supplemented). Then, samples were treated with different acidic proteases with a certain dosage of proteolytic 
activity at $25{ }^{\circ} \mathrm{C}, \mathrm{pH} 3.5 \pm 0.1$, and running for $180 \mathrm{~min}$. Finally, $0.2-0.4 \%$ of $\mathrm{H}_{2} \mathrm{SO}_{4}$ was added into each drum after maintaining the final pickling $\mathrm{pH}$ of about $2.8 \pm 0.1$, drums were left overnight. After pickling overnight, the concentration of soluble protein (SP) and Hypro in the reaction liquors was tested according to the steps described in the following concentration measuring method section. The opening up of collagen fibers and elastin fibers residues were observed with an optical microscope after staining by aldehyde-fuchsin method [34] and Weigert-Van Gieson method [35], respectively.

After overnight pickling, $6.5 \%$ of chrome powder was added to each drum and running for $240 \mathrm{~min}$ at $25^{\circ} \mathrm{C}$ to ensure that chrome may completely penetrate the inner layer of the pelt. Then, the $\mathrm{pH}$ was basified to around $4.0 \pm 0.1$ with $\mathrm{NaHCO}_{3}$ solution carefully. Then a certain amount of hot water $\left(60{ }^{\circ} \mathrm{C}\right)$ was added to achieve $200 \%$ total water offer of limed hide weight. After 120 min of running at $40{ }^{\circ} \mathrm{C}$, the drums were allowed to stay overnight. On the next day early morning, the $\mathrm{pH}$ of tanning liquors was adjusted to $4.0 \pm 0.1$ once again. The chromium content in spent liquors and wet blue was determined. The shrinkage temperature $\left(T_{s}\right)$ and grain pattern of the wet blue from the adjacent and symmetrical parts of the same hide were determined and observed, respectively. Then, wet blue samples were neutralized, retanned, fatliquored, squeeze-spread, toggle-dried and milled as per the same standard post-tanning procedures. The softness and main physical properties of the crust leathers from the adjacent and symmetrical parts were evaluated. The organoleptic properties of these crust leathers were evaluated by 10 skilled professional tanners.

\subsection{Comparison of the bating effectiveness of acidic protease L80A and trypsin BEM}

A whole grain-layer limed cattle hide with a thickness of $3.0-3.2 \mathrm{~mm}$ after splitting was divided into two pieces adjacently and symmetrically. A piece of the delimed pelt was pickled, bated with $150 \mathrm{U} / \mathrm{mL}$ of acidic protease L80A, and chrome tanned according to the procedure Sect. 2.5. Another piece from delimed pelt was trypsin bated, pickled, and chrome tanned as the following procedures: $50 \%$ of water (based on the weight of limed hides, the same below) and $1.0 \%$ of commercial trypsin BEM running for $60 \mathrm{~min}$ at $\mathrm{pH} 8.5$ and $33^{\circ} \mathrm{C}$; and washed with $200 \%$ water for two times. Then, the pelts were pickled and chrome tanned with the above-mentioned pickling-chrome tanning procedure except for acidic bating operation. Then, wet blue samples were neutralized, retanned, fatliquored, squeeze-spread, toggle-dried and milled as per the same standard post-tanning procedures.

\subsection{Determination of soluble protein (SP) concentration in bating liquor}

After the end of pickling, the concentration of SP was determined according to the modified Lowry method [36]. First, the reaction liquors were filtered with a qualitative filter paper and diluted into a certain concentration with ultrapure water. Then, $1 \mathrm{~mL}$ of the filtrate was mixed with $5 \mathrm{~mL}$ of Folin-phenol reagent- $\mathrm{A}$ at room temperature for $10 \mathrm{~min}$. Next, $0.5 \mathrm{~mL}$ of Folin-phenol reagent-B was added and incubated at $30{ }^{\circ} \mathrm{C}$ for $30 \mathrm{~min}$. Finally, the absorbance of the mixture was measured at $660 \mathrm{~nm}$ to determine the amount of SP.

\subsection{Determination of hydroxyproline concentration in bating liquor}

After the end of pickling, the concentration of Hypro was determined according to the modified colorimetric method [32]. First, the reaction liquors were filtered with a qualitative filter paper, and $2 \mathrm{~mL}$ of the filtrate was mixed with $2 \mathrm{~mL}$ of hydrochloric acid $(12 \mathrm{~mol} / \mathrm{L})$ in a $10 \mathrm{~mL}$ COD digestion tube $(\mathrm{HACH}$, America). The mixture was hydrolyzed in a COD digestion reactor (571-1, INESA Co., Ltd., China) at $120^{\circ} \mathrm{C}$ for $4 \mathrm{~h}$. A colored soluble product was obtained based on the reaction of Hypro with $p$-dimethylaminobenzaldehyde. The absorbance of the colored mixture was measured at $560 \mathrm{~nm}$ to determine the amount of Hypro.

\subsection{Determination of chromium content in spent tanning liquors and wet blue}

The spent tanning liquors were filtered with a qualitative filter paper, and $2 \mathrm{~mL}$ of the filtrate was digested with the mixture of hydrogen peroxide and nitric acid at $120{ }^{\circ} \mathrm{C}$ for $120 \mathrm{~min}$ in a $10 \mathrm{~mL}$ COD digestion tube (HACH, America). Then, the digested liquor was cooled to room temperature, appropriately diluted with ultrapure water, and the concentration of chromium was determined by Inductively Coupled Plasma Emission Spectrometer method (AES-ICP, 2100DV, Perkin Elmer Inc., America). The chromium concentration of the spent tanning liquors was calculated.

Wet blue samples were taken out from the adjacent and symmetrical parts of the same hide and freeze-dried. Then, $100 \pm 1 \mathrm{mg}$ of the dried wet blue was digested with the mixture of hydrogen peroxide and nitric acid as the above-mentioned method. The digestion solutions were appropriately diluted and the concentration of chromium was detected with AESICP method. The chromium content in the wet blue was calculated. 


\subsection{Histological analysis of collagen and elastin fiber} Samples of $1 \mathrm{~cm}^{2}$ were cut from the adjacent and symmetrical parts of the corresponding bated pelt and fixed in a neutral formaldehyde solution $(10 \%, v / v)$ for $24 \mathrm{~h}$ [35, 37]. Sections of $20 \mu \mathrm{m}$ and $12 \mu \mathrm{m}$ thicknesses were obtained using CM1950 freezing microtome (Leica, Germany) and stained by the aldehyde-fuchsin staining method and Weigert-Van Gieson staining method, respectively. The residues of elastin fiber and the opening up of collagen fiber were observed with an optical microscope (Nexcope NE900, Ningbo Yongxin Optics Co. Ltd., China).

\subsection{Scanning electron microscopy (SEM) analysis}

The wet blue leathers from each bating group were taken out in the adjacently and symmetrically parts of the same hide and freeze-dried. Samples were coated with gold using an SBC-12 Sputter Coater (KYKY Co., Ltd., China) and introduced into the specimen chamber of a Phenom Pro Desktop Scanning Electron Microscope (Phenom World Inc., Netherland). The micrographs of the grain layer were obtained by operating the microscope at a higher voltage.

\subsection{Test of softness and physical properties of crust leather}

Dried crust leather samples from each enzyme bating group were taken out from the adjacent and symmetrical parts of the same leather for testing softness and physical properties. Samples were conditioned as per the IUP method (IUP 2, 2000). The softness of the crust leather was determined with a Leather Softness Tester (GT-303, Gotech Testing Machines Inc., China). The physical properties such as tensile strength, elongation at break, tear strength and bursting strength were examined as per the standard procedures (Luo et al. 2012; IUP 6, 2000; IUP 8, 2000; IUP 9, 2000).

\section{Results}

\subsection{Proteolytic characteristics of typical acidic proteases}

\subsubsection{Salt-tolerance of acidic proteases}

The results in Fig. 1 illustrate that the collagenolytic activity of these acidic proteases was slight decreased with the increase of $\mathrm{NaCl}$ concentration from 50 to $120 \mathrm{~g} / \mathrm{L}$. The relative collagenolytic activity of these proteases remained $90 \%$ even the concentration of $\mathrm{NaCl}$ was augmented to $120 \mathrm{~g} / \mathrm{L}$, indicating their adaptability for the pickling-bating conditions as the conventional pickling operation almost always contains $60-100 \mathrm{~g} / \mathrm{L}$ of $\mathrm{NaCl}$.

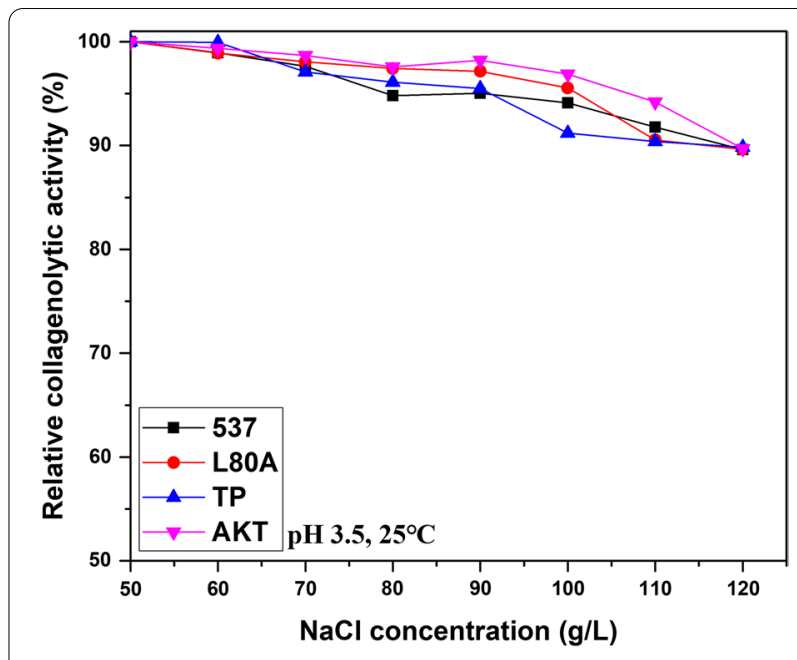

Fig. 1 Influence of $\mathrm{NaCl}$ concentration on the collagenolytic activity of acidic proteases $\left(\mathrm{pH} 3.5,25^{\circ} \mathrm{C}\right)$

\subsubsection{Effect of $p H$ on caseinolytic and collagenolytic activities of acidic proteases}

To further analyze the characteristics of acidic proteases in pickling-bating conditions, the effect of $\mathrm{pH}$ on the caseinolytic and collagenolytic activities was investigated through Folin and Collagen-fiber-substrate methods, respectively. The optimum working $\mathrm{pH}$ values of these proteases were studied in the range of 2.05.0 at $25{ }^{\circ} \mathrm{C}$, and the real reaction $\mathrm{pH}$ of the proteases towards collagen fiber was tested after the B-R buffer was mixed with the collagen fiber substrate, simultaneously. The results in Fig. 2 shows that the effect of $\mathrm{pH}$ on the proteolytic activities determined by different methods was found to be significantly different. Figure 2a indicate that all of these proteases exhibited the maximum caseinolytic activity at $\mathrm{pH} 3.5$. Figure $2 \mathrm{~b}$ indicate that protease 537 and AKT revealed the optimum collagenolytic activity at $\mathrm{pH} 3.5$, whereas, the optimum $\mathrm{pH}$ for protease L80A and TP was found to be in the range of 3.0-4.0. Hence, pH 3.5 was chosen as the optimal pH for the following pickling-bating condition.

Considering the optimal pickling-bating application conditions at $\mathrm{pH} 3.5$ and $25{ }^{\circ} \mathrm{C}$, Table 2 shows that among all the proteases, the highest relative activity was produced by protease L80A while the minimum was by protease 537 . Further, all of these acidic proteases exhibited much higher activity to casein substrate than that of collagen fiber substrate. The collagenolytic activity to 1 unit of caseinolytic activity $(\mathrm{H} / \mathrm{F})$ was 0.06 $\mathrm{U}$ for proteases AKT and L80A. The H/F value for protease TP was 0.05 . However, the observed $H / F$ value for protease 537 was $0.23 \mathrm{U}$, significantly higher than other acidic proteases. 
a

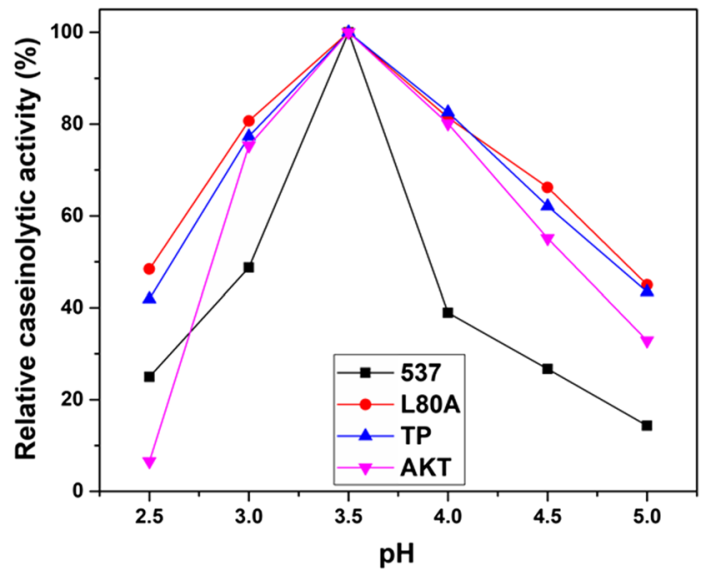

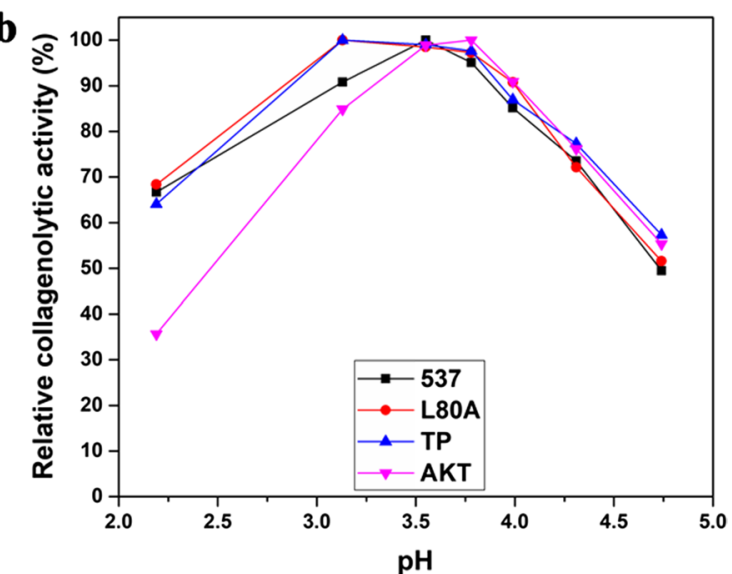

Fig. 2 a Effect of $\mathrm{pH}$ on the caseinolytic activity of acidic proteases $\left(25^{\circ} \mathrm{C}\right)$. $\mathbf{b}$ Effect of pH on the collagenolytic activity of acidic proteases $\left(25^{\circ} \mathrm{C}\right.$, $\mathrm{NaCl}$ concentration is $80 \mathrm{~g} / \mathrm{L}$ )

Table 2 Enzymatic characteristics of acidic proteases $\left(25^{\circ} \mathrm{C}, \mathrm{pH}\right.$ 3.5)

\begin{tabular}{llll}
\hline $\begin{array}{l}\text { Commercial } \\
\text { proteases }\end{array}$ & $\begin{array}{l}\text { Caseinolytic } \\
\text { activity }(\mathbf{F}, \mathbf{U} / \mathbf{g})\end{array}$ & $\begin{array}{l}\text { Collagenolytic } \\
\text { activity }(\mathbf{H}, \mathbf{U} / \mathbf{g})\end{array}$ & $\mathbf{H} / \mathbf{F}$ \\
\hline 537 & 9967 & 2282 & 0.23 \\
AKT & 222,049 & 14,080 & 0.06 \\
TP & 337,956 & 17,313 & 0.05 \\
L80A & 745,459 & 41,435 & 0.06 \\
\hline
\end{tabular}

\subsection{Comparison bating effectiveness of different acidic proteases in pickling process}

\subsubsection{Bating effectiveness of pickling pelts with same caseinolytic activity concentration}

The bating effectiveness of the above-mentioned acidic proteases was compared at the same pickling condition to select the appropriate pickling-bating enzyme. Four different acidic proteases were chosen for bating pickling pelts with the same dosages of caseinolytic activity concentration $(\mathrm{cF}), 2236 \mathrm{U} / \mathrm{mL}$ reaction liquor, based on the previous results. Table 3 shows that the observed concentration of collagenolytic activity $(\mathrm{cH})$ in the bating liquor for protease AKT, TP and L80A was approximately $127 \mathrm{U} / \mathrm{mL}$. However, it was significantly higher (512 U/ $\mathrm{mL}$ ) for protease 537 .

After bating and overnight stay, the concentration of SP and Hypro in the pickling-bating liquors was measured. The results in Table 3 indicate that approximately $1087 \mu \mathrm{g} / \mathrm{mL}$ and $127 \mu \mathrm{g} / \mathrm{mL}$ SP and Hypro were present in the bating liquors with the application of AKT, TP, and L80A. However, this amount was significantly higher $(550 \mu \mathrm{g} / \mathrm{mL})$ when protease 537 was applied. Furthermore, with the same caseinolytic activity concentration, the content of SP hydrolyzed by 1 unit of caseinolytic activity $(\mathrm{SP} / \mathrm{F})$ was found to be $0.505 \pm 0.081 \mu \mathrm{g}$ for all the acidic proteases; the content of Hypro hydrolyzed by 1 unit of collagenolytic activity $(\mathrm{Hypro} / \mathrm{H})$ was approximately $1.030 \pm 0.123 \mu \mathrm{g}$.

Table 3 Amounts of proteases, soluble protein, hydroxyproline in the bating liquor and the softness of crust leather treated by the same dosage of caseinolytic activity $\left(25^{\circ} \mathrm{C}, \mathrm{pH} 3.5\right)$

\begin{tabular}{|c|c|c|c|c|c|c|}
\hline Proteases & Dosage (\%) & $\mathrm{cF}^{* a}(\mathrm{U} / \mathrm{mL})$ & $\mathrm{cH}^{* \mathrm{~b}}(\mathrm{U} / \mathrm{mL})$ & $S P^{* c}(\mu \mathrm{g} / \mathrm{mL})$ & Hypro $^{* d}(\mu \mathrm{g} / \mathrm{mL})$ & Softness $(\mathrm{mm})$ \\
\hline 537 & 11.219 & 2236 & 512 & 1262 & 562 & 6.63 \\
\hline AKT & 0.504 & 2236 & 142 & 1133 & 131 & 7.32 \\
\hline $\mathrm{TP}$ & 0.331 & 2236 & 115 & 1076 & 137 & 8.28 \\
\hline L80A & 0.150 & 2236 & 124 & 1062 & 150 & 8.22 \\
\hline Control & 0 & 0 & 0 & 3 & 12 & 6.54 \\
\hline
\end{tabular}

*a: $\mathrm{CF}$ represents the concentration of caseinolytic activity in the bating liquor

*b: $\mathrm{CH}$ represents the concentration of collagenolytic activity in the bating liquor

${ }^{*} \mathrm{C}$ : SP represents the concentration of produced soluble protein in the bating liquor

${ }^{*} \mathrm{~d}$ : Hypro represents the concentration of produced hydroxyproline in the bating liquor 
Further, the pickling pelts were chrome tanned, retanned, fatliquored and dried as per the same standard procedures. The softness of these crust leather was tested and the organoleptic properties were evaluated by 10 skilled professional tanners. They unanimously commented that the crust leather treated by protease L80A, $\mathrm{AKT}$ and TP was significantly better than protease 537 in respect of softness, hand feeling, etc. Table 3 also shows that protease TP and L80A produced highly soft crust leather whereas this characteristic was missing in the protease 537 produced leather.

\subsubsection{Bating effectiveness of pickling pelts with same collagenolytic activity concentration}

To compare the bating effectiveness of these acidic proteases, selected proteases were chosen for bating pickling pelts with the same dosages of collagenolytic activity concentration $(\mathrm{cH}), 150 \mathrm{U} / \mathrm{mL}$ reaction liquor. The amounts of soluble protein and Hydroxyproline in the bating liquor were also measured. Table 4 shows that the concentration of caseinolytic activity $(\mathrm{cF})$ in the bating liquor for protease AKT, TP and L80A was approximately $2644 \mathrm{U} /$ $\mathrm{mL}$ compared to $655 \mathrm{U} / \mathrm{mL}$ for protease 537 .

The results in Table 4 shows that with the same concentration of collagenolytic activity, approximately $177 \mu \mathrm{g} /$ $\mathrm{mL}$ of Hypro was produced by all of these acidic proteases. The produced amounts of SP in AKT, TP, L80A and 537 bating liquor were approximately $1100 \mu \mathrm{g} / \mathrm{mL}$ and $655 \mu \mathrm{g} / \mathrm{mL}$, respectively. Furthermore, the content of Hypro hydrolyzed by 1 unit of collagenolytic activity (Hypro/H) was approximately $1.179 \pm 0.083 \mu \mathrm{g}$; and the content of SP hydrolyzed by 1 unit of caseinolytic activity $(\mathrm{SP} / \mathrm{F})$ was $0.417 \pm 0.070 \mu \mathrm{g}$ for all of these acidic proteases.

Also, all of these pickling-bating pelts were carried out with the same standard chrome tanning and post-tanning procedures, and the softness and organoleptic properties of these crust leathers were evaluated. The results in Table 4 indicate that better softness in crust leather was produced by protease AKT, TP, and L80A as compared to protease 537 . Besides, the softness and organoleptic properties of the crust leather treated by protease L80A were better than that of protease AKT and TP. In contrast, protease 537 failed to induce any improvement in the overall quality of crust leather rather it produced stiffer leather as compared to the control.

On the way forward to select an appropriate picklingbating enzyme, we had compared the bating effectiveness of different typical acidic proteases with the same dosage of caseinolytic and collagenolytic activity, respectively. These results suggested that the bating effectiveness of acidic proteases on pickling pelts mainly depends on the relative activity, namely the purity of active proteins, especially the collagenolytic activity, i.e. proteases with high collagenolytic activity and purity can significantly improve the softness of the crust leather. Furthermore, acidic protease L80A revealed a better bating effect than the rest of the acidic proteases at the same dosages and bating conditions. Hence, acidic protease L80A was chosen as the pickling-bating enzyme for the following study.

\subsection{Relationship between collagenolytic activity and bating effect of pickling pelts}

It is obvious that raising the concentration of collagenolytic activity is beneficial in the production of soft crust leather that comes from the further opening-up of collagen fiber. On the other hand, the whole properties of the final leather, such as the hand feeling, mechanical properties, grain layer state, largely rely on the proteolysis degree of the structural proteins, namely elastin and collagen fibers. Our research proved that acidic proteases almost have no effect on elastin fibers, therefore, the proteolytic activity towards collagen fibers may have large influences on the bating effectiveness of pickling pelts. Hence, the relationship between collagenolytic activity and bating effect of pickling pelts was studied by using

Table 4 Amounts of proteases, soluble protein, hydroxyproline in the bating liquor and the softness of crust leather treated by the same dosage of collagenolytic activity $\left(25^{\circ} \mathrm{C}, \mathrm{pH} 3.5\right)$

\begin{tabular}{|c|c|c|c|c|c|c|}
\hline Proteases & Dosage (\%) & $\mathrm{cF}^{* \mathrm{a}}(\mathrm{U} / \mathrm{mL})$ & $\mathrm{cH}^{* \mathrm{~b}}(\mathrm{U} / \mathrm{mL})$ & $S P^{* c}(\mu \mathrm{g} / \mathrm{mL})$ & Hypro $^{* d}(\mu \mathrm{g} / \mathrm{mL})$ & Softness (mm) \\
\hline 537 & 3.287 & 655 & 150 & 282 & 174 & 6.44 \\
\hline AKT & 0.533 & 2366 & 150 & 1047 & 208 & 7.80 \\
\hline TP & 0.433 & 2928 & 150 & 1101 & 183 & 7.58 \\
\hline L80A & 0.181 & 2699 & 150 & 1168 & 191 & 8.02 \\
\hline Control & 0 & 0 & 0 & 6 & 12 & 6.46 \\
\hline
\end{tabular}

*a: cF represents the concentration of caseinolytic activity in the bating liquor

*b: $\mathrm{cH}$ represents the concentration of collagenolytic activity in the bating liquor

${ }^{*} \mathrm{C}$ : SP represents the concentration of produced soluble protein in the bating liquor

${ }^{*} \mathrm{~d}$ : Hypro represents the concentration of produced hydroxyproline in the bating liquor 


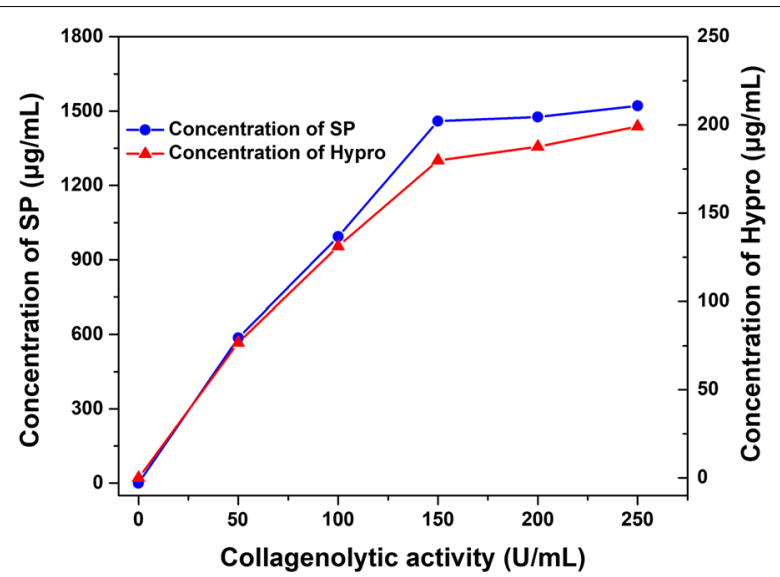

Fig. 3 Concentration of soluble protein and hydroxyproline in the bating liquor vs. collagenolytic activity concentration of acidic protease L80A $\left(25^{\circ} \mathrm{C}, \mathrm{pH} 3.5\right)$ acidic protease L80A as the selected pickling-bating enzyme.

The results in Fig. 3 demonstrate that the higher the collagenolytic activity, the larger would be the concentration of SP and Hypro produced in the reaction liquor. Furthermore, both concentrations of SP and Hypro increased linearly with the increase of protease L80A dosage in the range of $0-150 \mathrm{U} / \mathrm{mL}$. However, the produced amounts of SP and Hypro remained constant when the concentration of collagenolytic activity was higher than $150 \mathrm{U} / \mathrm{mL}$, which were approximately $1500 \mu \mathrm{g} / \mathrm{mL}$ and $190 \mu \mathrm{g} / \mathrm{mL}$, respectively.

In addition, the grain layer of the crust leather treated by different dosages of acidic protease L80A was observed through SEM. Figure 4 shows evidence that after being treated with acidic protease L80A, the grain layer of the crust leathers had no obvious difference than the control, and the grain layer and hair pores were clearly visible without any surface damage in the range of collagenolytic activity concentration $0-250 \mathrm{U} / \mathrm{mL}$.

Table 5 shows that the softness of the crust leather was improved with the increase of the dosage of protease
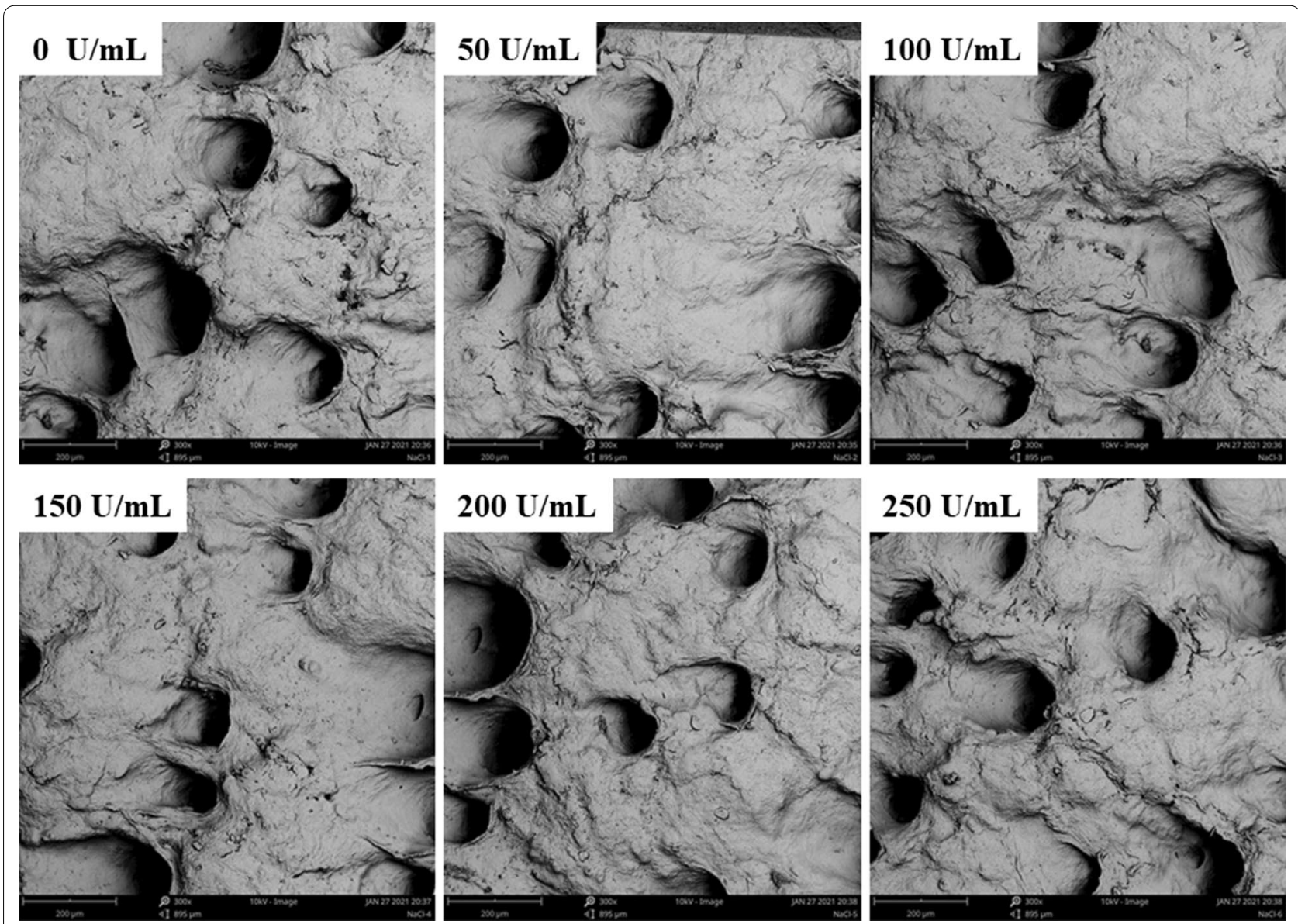

Fig. 4 SEM images of grain layer of the crust leathers treated by different dosages of protease L80A $(300 \times)$ 
Table 5 Relation of the softness and physical properties of the crust leathers to the collagenolytic activity of protease $\mathrm{L} 80 \mathrm{~A}\left(25^{\circ} \mathrm{C}\right.$, $\mathrm{pH}$ 3.5)

\begin{tabular}{|c|c|c|c|c|c|c|c|}
\hline Dosage (\%) & $\begin{array}{l}\text { Collagenolytic } \\
\text { activity }(\mathrm{U} / \mathrm{mL})\end{array}$ & Softness (mm) & $\begin{array}{l}\text { Tear strength } \\
(\mathrm{N} / \mathrm{mm})\end{array}$ & $\begin{array}{l}\text { Tensile strength } \\
\left(\mathrm{N} / \mathrm{mm}^{2}\right)\end{array}$ & $\begin{array}{l}\text { Elongation at } \\
\text { break (\%) }\end{array}$ & $\begin{array}{l}\text { Bursting } \\
\text { strength }(\mathrm{N} / \mathrm{mm})\end{array}$ & $\begin{array}{l}\text { Bursting } \\
\text { height } \\
(\mathrm{mm})\end{array}$ \\
\hline 0 & 0 & 7.04 & 34.94 & 8.76 & 58.36 & 203.31 & 10.70 \\
\hline 0.060 & 50 & 7.91 & 37.75 & 10.74 & 56.29 & 212.94 & 12.40 \\
\hline 0.121 & 100 & 8.18 & 40.79 & 13.22 & 53.55 & 214.22 & 10.59 \\
\hline 0.181 & 150 & 8.21 & 50.79 & 13.42 & 49.87 & 229.94 & 11.59 \\
\hline 0.241 & 200 & 8.26 & 64.97 & 13.62 & 53.90 & 333.34 & 14.01 \\
\hline 0.302 & 250 & 8.40 & 61.58 & 14.01 & 58.62 & 246.25 & 13.01 \\
\hline
\end{tabular}

L80A, however, the mechanical properties of these enzyme-treated leathers were higher or comparable to the control. The tear strength, tensile strength, and bursting strength were increased with the increase of the collagenolytic activity in the range of 50-200 U/mL. However, the tear strength and bursting strength were significantly decreased when the concentration of collagenolytic activity reached up to $250 \mathrm{U} / \mathrm{mL}$. Roundness, fullness, grain-tightness, grain-smoothness, filling, looseness, and hand feeling, and the overall quality of the finished leather treated by $150 \mathrm{U} / \mathrm{mL}$ of protease $\mathrm{L} 80 \mathrm{~A}$ were significantly better than the rest of the leathers.

So far, our work has led us to conclude that a reliable pickling pelt bating method can be achieved by fulfilling the following experiment conditions: $\mathrm{pH}, 3.5 \pm 0.1$; temperature, $25{ }^{\circ} \mathrm{C}$; running $180 \mathrm{~min}$; after the addition of approximately $150 \mathrm{U} / \mathrm{mL}$ collagenolytic activity acidic protease L80A acidic protease; then, the addition of a certain amount of $\mathrm{H}_{2} \mathrm{SO}_{4}$ to ensure the final pickling $\mathrm{pH}$ around $2.8 \pm 0.1$ and overnight stay at room temperature followed by chrome tanning operation.

\subsection{Comparison of bating effectiveness of the novel pickling-bating and conventional trypsin bating method}

As mentioned above, acidic proteases can work well in an acidic medium. They have low proteolysis ability towards collagen fiber and almost have no effect on elastin fiber. All of these characteristics make the acidic proteases favorable candidates to replace the conventional trypsin bating method. In this study, the bating effectiveness of the novel pickling-bating system by using acidic protease L80A was compared with the conventional delimingbating system by using a commonly used pelts bating product, trypsin BEM. As shown in Table 6, the concentration of proteolytic activities, the produced amount of SP, Hypro and desmosines (Des) in the bating liquors were measured after bating; the shrinkage temperature $\left(T_{s}\right)$, the chromium content in the effluent and wet blue
Table 6 Amounts of protease and testing results of the effluents and crust leathers

\begin{tabular}{lll}
\hline Test item & $\begin{array}{l}\text { Acidic } \\
\text { protease } \\
\text { L80A }\end{array}$ & Trypsin BEM \\
\hline Dosage $(\%)$ & 0.181 & 1.000 \\
Caseinolytic activity $(\mathrm{U} / \mathrm{mL})$ & 2699 & 17 \\
Collagenolytic activity $(\mathrm{U} / \mathrm{mL})$ & 150 & 103 \\
Elastinolytic activity $(\mathrm{U} / \mathrm{mL})$ & 0 & 1.0 \\
SP concentration $(\mu \mathrm{g} / \mathrm{mL})$ & 1626 & 2010 \\
Hypro concentration $(\mu \mathrm{g} / \mathrm{mL})$ & 152 & 67 \\
Desmosine concentration $(\mu \mathrm{g} / \mathrm{mL})$ & 0 & 0.4 \\
Chromium in the effluent liquor $(\mathrm{mg} / \mathrm{L})$ & 715 & 727 \\
Chromium in wet blue $(\%)$ & 2.45 & 2.21 \\
Shrinkage temperature $\left({ }^{\circ} \mathrm{C}\right)$ & 114.1 & 104.2 \\
Softness (mm) & 8.83 & 8.40 \\
Tear strength $(\mathrm{N} / \mathrm{mm})$ & 82.63 & 70.40 \\
Tensile strength $\left(\mathrm{N} / \mathrm{mm}{ }^{2}\right)$ & 13.31 & 9.92 \\
Elongation at break $(\%)$ & 52.76 & 44.55 \\
Bursting strength $(\mathrm{N} / \mathrm{mm})$ & 422.41 & 320.34 \\
Bursting height $(\mathrm{mm})$ & 15.03 & 13.96 \\
\hline
\end{tabular}

leathers were measured after chrome tanning; the softness and main physical properties of the crust leathers from the adjacent and symmetrical parts were also evaluated.

Table 6 shows that the dosage of protease in the bating liquors for the acidic bating method and trypsin bating method was $0.181 \%$ and $1.000 \%$, respectively. The collagenolytic activity to 1 unit of caseinolytic activity (H/F) of acidic protease L80A and trypsin BEM was $0.06 \mathrm{U}$ and $6.06 \mathrm{U}$, respectively. The $\mathrm{H} / \mathrm{F}$ value of $\mathrm{BEM}$ was found to be 100 times higher than acidic protease L80A. The content of SP hydrolyzed by 1 unit of caseinolytic activity of L80A and BEM enzyme was $0.60 \mu \mathrm{g}$ and $118.24 \mu \mathrm{g}$, respectively; the content of Hypro hydrolyzed by 1 unit of collagenolytic activity of L80A and BEM enzyme 
was $1.01 \mu \mathrm{g}$ and $0.65 \mu \mathrm{g}$, respectively. Furthermore, the elastinolytic activity of the proteases and the produced amounts of Des were tested according to the reported methods [31, 38]. Table 6 illustrates that trypsin BEM had an effect on elastin fiber and produced $0.4 \mu \mathrm{g} / \mathrm{mL}$ of Des in the bating process, inversely, acidic protease L80A had no effect on elastin fiber. Furthermore, the content of chromium and the shrinkage temperature of the wet blue treated by protease L80A were found to be a little higher than that of BEM. Table 6 also shows that the softness and physical properties of protease L80A treated crust leather were better than that of BEM.

Furthermore, Fig. 5a shows that many elastin fibers in the form of branches remained in the grain layer of protease L80A bated sample. However, most of the elastin fibers were removed by BEM, and the elastin fibers around hair follicles have barely existed. The SEM images in Fig. $5 \mathrm{c}$ indicate that the grain layer of the leather bated by protease L80A was clearly visible without any surface damage. Conversely, the gain layer of the leather bated by BEM had some degree of damage as indicated by the red arrows, which might be due to the degradation of elastin fibers in the grain layer. Figure $5 \mathrm{~b}$ shows that protease L80A opened up more collagen fibers than that of BEM, making the finished leather softer. On the other hand, most of the fiber bundles treated by trypsin BEM were still bonded together. Additionally, all the professional tanners unanimously agreed that the whole quality of the finished leather treated by acidic protease L80A was better than that of trypsin BEM in the respect of softness, organoleptic properties, and physical properties.

\section{Discussion}

Trypsin has been used in leather bating process for many years to open up protein structure, remove noncollagenous proteins and inter-fibrillary substances from delimed pelts for the effective penetration and coalescent of tanning and post-tanning agents. Trypsin is regarded as the most appropriate enzyme for pelt bating. High hydrolysis specificity to protein substances and moderate proteolytic activity are some of the fundamental characteristics of trypsin. However, the use of trypsin in leather manufacturing is restricted because of two reasons. First, commercial product of trypsin mainly depends on its extraction from bovine pancreatic tissue. This process suffers from many disadvantages, such as limited availability of raw material, contamination of extracted enzymes with a series of different active enzyme components, poor batch stability of industrial products, unpleasant odor, potential cross-infection and hazards to mammal immunogenicity, etc. Although, microbial product of trypsin has been considered as an attractive alternative approach to mammalian trypsin and received much attention in recent years $[14,17]$. However, the
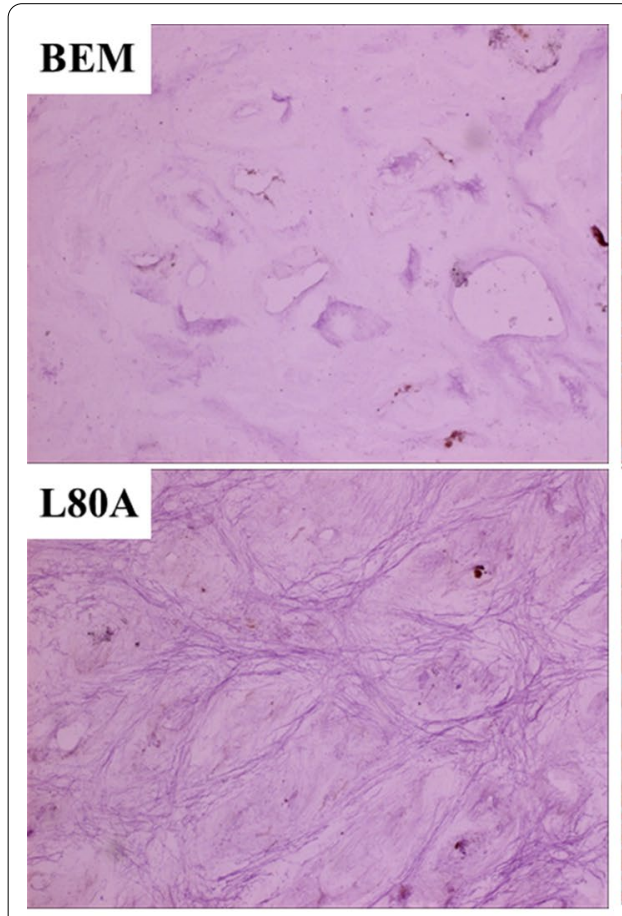

$\mathbf{a}$
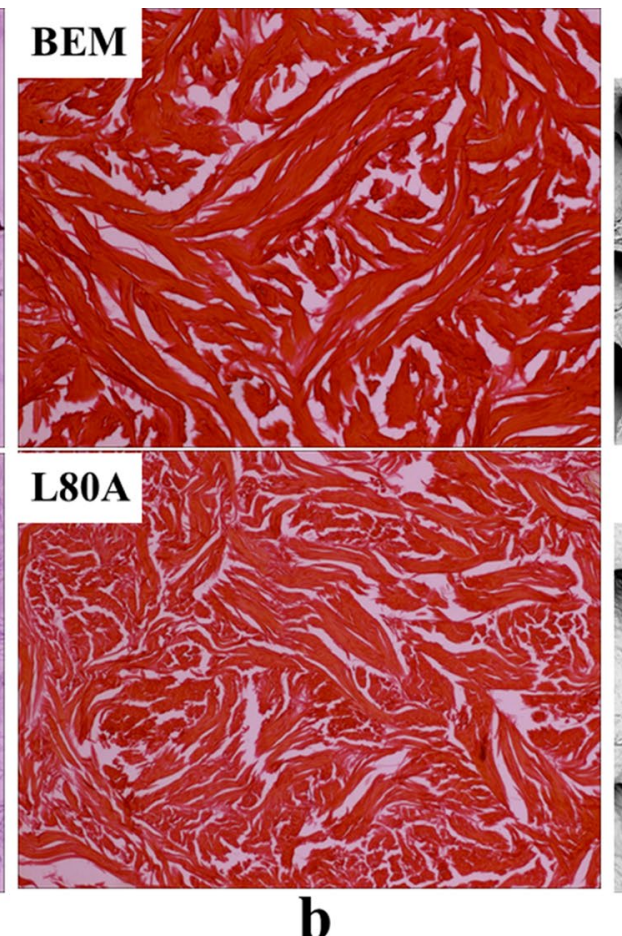
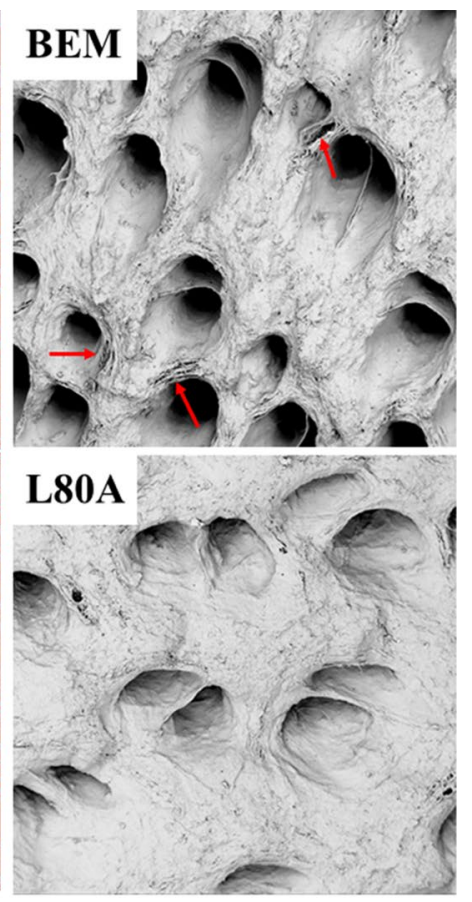

c

Fig. 5 a Residual of elastin fiber in grain layer $(100 \times$ hor.sec.); b Staining results of collagen fiber $(100 \times$ ver.sec.); c SEM images of grain layer $(300 \times)$ 
fermentation capacity, low stability, and self-degradation are some of the major pitfalls of this product. Additionally, most of the commercial products exhibit broadspectrum activities to all of the protein components of pelts, and different batches of commercial products have significant differences in terms of quality due to the purification and other variables. These shortcomings make to believe that the application of microbial trypsin in pelts bating process may cause an undue and non-selective damage to the collagen and elastin fibers leading to loose and damaged grain.

Our team has researched for many years to overcome the aforementioned shortcomings. Initially, we developed an accurate method for the quantitative characterization of protease activity of an enzyme by establishing methods capable of exactly determining the quantity of desmosine (a unique constituent of elastin) and hydroxyproline (a unique constituent of collagen) from reaction liquors.[24, $27,31,32]$. Then, we thoroughly investigated the activities of different types of proteases through Folin method, collagen-fiber-substrate method and elastin-fiber-substrate method, respectively. Our research found that microbial acidic proteases almost have no effect on elastin fiber and a slight effect on collagen fiber; microbial neutral proteases have an obvious effect on collagen fiber and a slight effect on elastin fiber; most of the microbial alkaline proteases have an obvious effect both on collagen and elastin fibers [24, 31, 39]. Therefore, it can be speculated that acidic proteases may have more efficacy in pelts bating process due to their moderate proteolytic ability and specificity availability than that of microbial and mammal trypsin.

Generally, in the conventional chrome tanning process, the pickle float must at least contain $60 \mathrm{~g} / \mathrm{L}$ of $\mathrm{NaCl}$ to protect the collagen fiber from acid swelling, which would have a serious negative influence on the organoleptic and physical properties of the leather. High salt concentration has always been used to loosen the bonding between decorin and collagen, thus rendering the proteoglycan more susceptible to proteolysis and removal from the hide [3]. However, high concentration of salt may have a negative effect on the proteolysis ability of enzymes. Therefore, the salt-tolerance of the selected typical acidic proteases must have to be taken into consideration at the very beginning. Figure 1 shows that all of the selected acidic proteases had good salt-tolerance at the conditions of $\mathrm{pH} 3.5,25{ }^{\circ} \mathrm{C}, 50 \mathrm{~g} / \mathrm{L}$ to $120 \mathrm{~g} / \mathrm{L} \mathrm{NaCl}$ concentration, indicating their natural adaptability to the pickling-bating conditions.

The end $\mathrm{pH}$ of pickling is usually adjusted to below 3.0 to ensure the penetration of chromium into the inner layer of the pelt and the deterrence of chrome overload on the grain layer. However, proteolysis characteristics of enzymes are greatly related to the $\mathrm{pH}$ of the reaction liquid and temperature. The temperature of pickling process is necessarily maintained at lower than $25{ }^{\circ} \mathrm{C}$ to avoid the thermal destruction and microbial degradation of dermis matrix. Therefore, in our experiments, the pickling-bating process was carried out at $25^{\circ} \mathrm{C}$ to exploit the maximum utilization of the proteolysis ability of the selected enzymes. The enzymatic characteristics of these acidic proteases towards casein and collagen fiber substrates were investigated. The results in Fig. 2 reveal that the effect of $\mathrm{pH}$ on the proteolytic activities determined by different methods were found to be significantly diverse. Compared with the general pickling-chrome tanning operation, $\mathrm{pH} 3.5$ was chosen as the optimal $\mathrm{pH}$ for the pickling-bating process. Subsequently, a certain amount of $\mathrm{H}_{2} \mathrm{SO}_{4}$ was also added to meet the needs of pickling-chrome tanning. Table 2 indicates that all acidic proteases exhibited relatively higher activity to casein substrate than collagen fiber substrate. The collagenolytic activity per unit of caseinolytic activity was found to be approximately $0.06 \mathrm{U}$ for AKT, TP and L80A enzymes, and $0.23 \mathrm{U}$ for protease 537 . As far as the purity was concerned, protease 537 had the lowest purity among all of the acidic proteases.

Softness, overall quality and the physical properties of finished leather are some of the major contemplations of the leather industry while adopting a new bating enzyme. Besides, a novel bating method should be easy to implement without changing routine operations. Our previous SDS-PAGE and IEF-PAGE research work reported that all of the selected acidic proteases contain a variety of protein molecules; the molecular weight $\left(\mathrm{M}_{\mathrm{r}}\right)$ of the major component was approximately $45 \mathrm{kDa}$, and the isoelectric point value (pI) was found to be approximately 4.45-5.10 [21]. These results indicated that the molecular size and charge interaction between these acidic proteases have no obvious difference. Therefore, proteolytic activity may have a large influence on bating effectiveness of the pickling pelts. The bating effectiveness of acidic proteases has a positive correlation with their collagenolytic and caseinolytic activities, and a protease with high caseinolytic activity and moderate collagenolytic activity can significantly remove the inter-fibrillary substances in collagen fiber bundles and improve the softness of crust leather.

The results in Tables 3 and 4 indicate that the proteolysis degree of collagen fiber and removal of inter-fibrillary substances by AKT, TP and L80A enzymes were at the same level. This finding is in line with the results of the proteolysis characteristics investigation (Table 2). However, the bating effectiveness of acidic protease 537 was dissatisfactory even at a large dosage and higher collagenolytic activity concentration. It is pertinent to mention 
that industrial proteases always contain active enzyme protein, inactive protein and other non-protein components. The content of active proteins in protease 537 is lower than that of AKT, TP, and L80A that's the reason it is exhibiting the lowest activities per gram of enzymes. Therefore, with the same concentration of proteolytic activity, the ratio of inactive protein and other nonprotein components in protease 537 is significantly higher than that of AKT, TP and L80A, which may affect the penetration, distribution and reaction of active enzyme proteins. The results in Tables 3 and 4 indicate that acidic protease L80A had better bating efficiency than other acidic proteases at the same dosages and bating conditions.

Although, a protease with high collagenolytic activity can significantly improve the softness of crust leathers, excessive proteolysis of collagen structure is harmful to leather matrix and significantly affects the organoleptic and physical properties of the final leather product. Therefore, the relationship between collagenolytic activity concentration in the bating liquor, namely the proteolytic degree of collagen fiber, and bating effectiveness of the pickling pelts should be critically explored. The results in Fig. 3 shows that the amounts of soluble protein and hydroxyproline increased linearly with the increase of caseinolytic and collagenolytic activity concentrations, and the collagenolytic activity concentration ranging from 50 to $150 \mathrm{U} / \mathrm{mL}$, amounting to $0.060 \%$ to $0.181 \%$ enzyme dosage of limed pelt weight. However, the concentration of hydrolysate closely reached up to maximum volume at the mentioned bating conditions when the enzyme concentration was higher than $0.181 \%$. Furthermore, Fig. 4 and Table 5 indicate that acidic protease L80A could considerably improve the softness, organoleptic properties and whole quality of the finished leather without affecting the physical properties in the range of $50-200 \mathrm{U} / \mathrm{mL}$ collagenolytic activity.

Finally, to compare the novel pickling-bating method with the conventional trypsin bating method, acidic protease L80A and a commonly used pelt bating product BEM (the main active component is bovine trypsin) were used, respectively. Table 6 shows that the collagenolytic activity per unit of caseinolytic activity $(\mathrm{H} / \mathrm{F})$ of BEM (6.06 U) was 100 times higher than that of L80A (0.06 $\mathrm{U})$. The produced amount of soluble protein by BEM $(1626 \mu \mathrm{g} / \mathrm{mL})$ and L80A $(2010 \mu \mathrm{g} / \mathrm{mL})$ was comparatively close. However, the produced amount of hydroxyproline per unit of collagenolytic activity by BEM $(0.65 \mu \mathrm{g})$ was lesser than that of L80A $(1.01 \mu \mathrm{g})$. The produced amount of soluble protein per unit of caseinolytic activity by L80A $(0.60 \mu \mathrm{g})$ was appreciably lower than that of BEM $(118.24 \mu \mathrm{g})$. Furthermore, trypsin BEM had an obvious effect on elastin fiber than that of acidic protease $\mathrm{L} 80 \mathrm{~A}$, and this enzyme produces $0.4 \mu \mathrm{g} / \mathrm{mL}$ of desmosines in the reaction liquor, leading to loosening/ damage the grain layer. Besides, the bating duration time for BEM (pH 8.5 and $33{ }^{\circ} \mathrm{C}$ for $60 \mathrm{~min}$ ) was notably lower than that of L80A (180 min at $\mathrm{pH} 3.5 \pm 0.1$ and approximately $10 \mathrm{~h}$ at $\mathrm{pH} 2.8 \pm 0.1$ ), which leads to the smooth, gentle and even penetration and reaction of protease L80A. Conversely, BEM proteolysis proteins were mostly found on the surface of the pelt, such as the grain layer and flesh side. Therefore, at the given bating conditions, BEM had a more obvious effect on the grain layer than that of acidic protease L80A due to which notably more soluble proteins had been detected, even with lower caseinolytic and collagenolytic activities of BEM. Table 6 also shows that the acidic protease L80A produced softer crust leather than that of trypsin BEM. Therefore, it can be concluded that the novel pickling-bating method by using acidic protease L80A is a more effective bating method for pelts.

In addition, Table 6 also displays that the content of chromium and the shrinkage temperature of the wet blue treated by acidic protease L80A was a little higher than that of trypsin BEM. The physical properties of L80A treated crust leather were better than that of BEM. The histological and SEM results in Fig. 5 indicate that the grain layer of the crust leather obtained from protease L80A bating method was clearly visible without any surface and elastin damage. Oppositely, the grain layer of the crust leather from BEM bating method had some degree of damage due to the degradation of elastin fiber in the grain layer. Furthermore, L80A opened up more collagen fibers than that of BEM.

There are three obvious advantages of protease L80A that make it a favorable candidate for a novel pelt bating enzyme over the conventional deliming bating method based on trypsin BEM. First, cheaper and convenient large scale, stable and high quality/pure microbial acidic proteases production, conversely, complicatedness in acquiring the high pure and stable trypsin from animal sources at a large scale for commercial-scale application; Second, better bating effectiveness of acidic protease due to its moderate proteolytic ability and safer bating performance; Third, quenching of proteolytic activity of acidic proteases with the addition of chrome powder enabling the pelt bating operation to be performed along with pickling process without extra inactivation and washing operations.

\section{Conclusions}

Pelt bating effectiveness of several typical acidic proteases was thoroughly investigated, and a cutting-edge approach for pelt bating was developed by using acidic proteases L80A in pickling process. Bating effectiveness of the developed pickling-bating method was compared 
with that of the conventional trypsin bating method using trypsin BEM. Taken together, these findings suggest that the bating effectiveness of the newly developed method was comparable to and even better than that of the conventional trypsin bating method. Thoroughly, deep and even penetration of acidic protease L80A in the pelt and its moderate proteolytic ability enables it to produce soft, organoleptically stable and overall better quality crust leather as compared to the conventional trypsin bating method. Results made us to conclude that the developed one-bath pickling-bating-chrome tanning method has a higher probability to replace the conventional trypsin bating method.

\section{Abbreviations}

SP: Soluble protein; Hypro: Hydroxyproline; Des: Desmosines; F: Caseinolytic activity; H: Collagenolytic activity; SEM: Scanning electron microscope.

\section{Acknowledgements}

We thank Chun-xiao Zhang, Jin-wei Zhang, Ke-lin Shui, Qing-shuang Song, Zhong-hui Wang and all our group mates at Sichuan University for their kind helps.

\section{Authors' contributions}

$X Z$ and $B P$ conceived and designed the research, interpreted the data, and finalized conclusions. $X Z$ conducted experimental work and drafted the manuscript. BP and SAC revised the manuscript. $M G, Y Z$ and $Y Y$ assisted with experiments. All authors read and approved the final manuscript.

\section{Funding}

This work was financially supported by the National Key Research and Development Program of China (2017YFB0308402).

\section{Availability of data and materials}

All data generated or analyzed during this study are included in this published article.

\section{Declarations}

\section{Competing interests}

The authors declare that they have no competing interests.

\section{Author details}

${ }^{1}$ National Engineering Research Center of Clean Technology in Leather Industry, Sichuan University, Chengdu 610065, Sichuan, People's Republic of China. ${ }^{2}$ Key Laboratory of Leather Chemistry and Engineering of Ministry of Education, Sichuan University, Chengdu 610065, Sichuan, People's Republic of China. ${ }^{3}$ Zhejiang Tongtianxing Group Joint-Stock Co., Ltd., Quzhou 324022, Zhejiang, People's Republic of China.

Received: 9 May 2021 Accepted: 10 September 2021 Published online: 15 October 2021

\section{References}

1. Ding HY, Sun LG, Liang CJ. Action of pancreatin on residual epidermis of goatskin: examination via histological changes during bating. J Soc Leath Tech Ch. 2005;89(4):141-4.

2. Covington AD. Tanning chemistry: the science of leather. Cambridge: The Royal Society of Chemistry; 2011.

3. Khambhaty Y. Applications of enzymes in leather processing. Environ Chem Lett. 2020;18(3):747-69.
4. Thanikaivelan P, Rao JR, Nair BU, Ramasami T. Progress and recent trends in biotechnological methods for leather processing. Trends Biotechnol. 2004:22(4):181-8

5. Luo F, Zhong X, Gao M, Peng B, Long Z. Progress and mechanism of breaking glycoconjugates by glycosidases in skin for promoting unhairing and fiber opening-up in leather manufacture. A review. J Leath Sci Eng. 2020;2(1):1-16.

6. Gallego-Molina A, Mendoza-Roca JA, Aguado D, Galiana-Aleixandre MV Reducing pollution from the deliming-bating operation in a tannery: wastewater reuse by microfiltration membranes. Chem Eng Res Des. 2013;91(2):369-76.

7. Ranjithkumar A, Durga J, Ramesh R, Sundar VJ, Rose C, Muralidharan C. Studies on alkaline protease from Bacillus crolab MTCC 5468 for applications in leather making. J Am Leather Chem As. 2017;112(7):232-9.

8. Choudhary RB, Jana AK, Jha MK. Enzyme technology applications in leather processing. Indian J Chem Technol. 2004;11(5):659-71.

9. Jaouadi NZ, Rekik H, Elhoul MB, Rahem FZ, Hila CG, Aicha HSB, Badis A, Toumi A, Bejar S, Jaouadi B. A novel keratinase from Bacillus tequilensis strain Q7 with promising potential for the leather bating process. Int J Biol Macromol. 2015:79(8):952-64.

10. Zhang CX, Lin J, Jia XJ, Peng BY. A salt-free and chromium discharge minimizing tanning technology: the novel cleaner integrated chrome tanning process. J Clean Prod. 2016;112(1):1055-63.

11. Heidemann E. Fundamentals of leather manufacture. Eduard Roether KG: Darmstadt (1993).

12. Polaina J, MacCabe AP. Industrial enzymes: structure, function and applications. Berlin: Springer; 2007.

13. Olsen JV, Ong S, Mann M. Trypsin cleaves exclusively C-terminal to arginine and lysine residues. Mol Cell Proteom. 2004;3(6):608-14.

14. Zhang YF, Huang H, Yao XH, Du GC, Chen J, Kang Z. High-yield secretory production of stable, active trypsin through engineering of the $\mathrm{N}$-terminal peptide and self-degradation sites in Pichia pastoris. Bioresource Technol. 2018;247(1):81-7.

15. Goudarzi BG, Vaccine $R$, Institute $S$. A simple, fast and commercial method for trypsin purification from bovine pancreas. Vet J. 2011;24(9):33-9.

16. Gupta R, Rajput R, Sharma R, Gupta N. Biotechnological applications and prospective market of microbial keratinases. Appl Microbiol Biotechnol. 2013:97(23):9931-40.

17. Gong JS, Li W, Zhang DD, Xie MF, Yang B, Zhang RX, Li H, Lu ZM, Xu ZH, Shi JS. Biochemical characterization of an arginine-specific alkaline trypsin from Bacillus licheniformis. Int J Mol Sci. 2015;16(12):30061-74.

18. Mamun AA, Khan M, Akand NR, Khan SN, Hoq M. Characterization of an alkaline protease with high quality bating potential in leather processing from Bacillus licheniformis MZK05M9 mutant. Int J Bio Res. 2014;3(1):36-41.

19. Hameed A, Natt MA, Evans CS. Production of alkaline protease by a new Bacillus subtilis isolate for use as a bating enzyme in leather treatment. World J Microbiol Biotechnol. 1996;12(3):289-91.

20. Song Y, Wu S, Yang Q, Liu H, Zeng Y, Shi B. Factors affecting mass transfer of protease in pelt during enzymatic bating process. J Leath Sci Eng. 2019;1(1):26-35.

21. Everett AL, Willard HJ, Naghski J. Microscopic study of leather defects I. veininess in glazed calfskin. J Am Leather Chem As. 1966;61(3):112-25.

22. Kahsay T, Negash G, Hagos Y, Hadush B. Pre-slaughter, slaughter and postslaughter defects of skins and hides at the Sheba tannery and leather industry, Tigray region, northern Ethiopia. Onderstepoort J Vet Res. 2015;82(1):931-8.

23. Zhang X, Zhong X, Gao MC, Peng BY, Zhang CX. Enzymatic bating technology for wet blue: II. the basic properties and application effectiveness of typical acidic proteases. J Am Leather Chem As. 2020;115(12):444-52.

24. Zhang $X$, Wan XZ, Xian J, Peng BY. Enzymatic bating technology for wet blue: I. Characterization of protease activities towards chrome-tanned elastin and collagen fibers. J Am Leather Chem As. 2018;113(7):217-24.

25. Gowthaman K, Vikram S, Nishad FN, Raghava RJ. Solving vein marks defects problem through wet end process. J Am Leather Chem As. 2014;109(9):278-83.

26. Razzaq A, Shamsi S, Ali A, Ali Q, Sajjad M, Malik A, Ashraf M. Microbial proteases applications. Front Bioeng Biotechnol. 2019;7(110):1-20.

27. Xian J, Bu DY, Tian YX, Zhang CX, Peng BY, Long ZZ. Properties and bating effects of trypsins from different sources. Leath Sci Eng. 2020;30(03):40-6. 
28. Rinderknecht H, Geokas MC, Silverman P, Lillard Y, Haverback BJ. New methods for the determination of elastase. Clin Chim Acta. 1968;19(2):327-39.

29. Daamen WF, Hafmans T, Veerkamp JH. Comparison of five procedures for the purification of insoluble elastin. Biomaterials. 2001;14(22):1997-2005.

30. Song J, Tao WY, Chen WY. A way to reduce injury to skin in enzymatic unhairing. J Soc Leath Tech Ch. 2015;99(3):115-9.

31. Li Y, Zhang C, Luo F, Peng B. A new approach for quantitative characterization of hydrolytic action of proteases to elastin in leather manufacturing. Appl Microbiol Biotechnol. 2018;102(24):10485-94.

32. Zhang $X$, Bu DY, Tian YX, Xian J, Zhang CX, Peng BY. Optimization of method for determination of hydroxyproline in enzymatic hydrolysate of collagen fibers. Leath Sci Eng. 2019:29(03):25-30.

33. Mohamed Ahmed IA, Babiker EE, Mori N. pH stability and influence of salts on activity of a milk-clotting enzyme from Solanum dubium seeds and its enzymatic action on bovine caseins. LWT Food Sci Technol. 2010;43(5):759-64.

34. Sumner BEH. A histochemical study of aldehyde fuchsin staining. J R Microsc Soc. 1965;84(3):329-38.
35. Luo XM, Ding SL, Zhou QF. Leather and fur physical and chemical analysis. Beijing: China Light Industry Press; 2012.

36. Lowry OH, Rosebrough NJ, Farr AL, Randall RJ. Protein measurement with the Folin phenol reagent. J Biol Chem. 1951;193(1):265-75.

37. Sivasubramanian S, Manohar BM, Puvanakrishnan R. Mechanism of enzymatic dehairing of skins using a bacterial alkaline protease. Chemosphere. 2008;70(6):1025-34.

38. Zhang X, Gao MC, Zhang CX, Chattha SA, Peng BY. A rapid method for measuring elastin degradation and its application in leather manufacturing. J Am Leather Chem As. 2020;115(8):294-300.

39. Xu BB, Li CX, Wang RR, Zhang CX, Peng BY. The impact of proteases on elastin in leather manufacture. J Soc Leath Technol Ch. 2012;96(3):100-5.

\section{Publisher's Note}

Springer Nature remains neutral with regard to jurisdictional claims in published maps and institutional affiliations.

\section{Submit your manuscript to a SpringerOpen ${ }^{\circ}$ journal and benefit from:}

- Convenient online submission

- Rigorous peer review

- Open access: articles freely available online

- High visibility within the field

- Retaining the copyright to your article

Submit your next manuscript at $\boldsymbol{\nabla}$ springeropen.com 